\title{
Family Resilience Belief System: A Phenomenological Study on Javanese and Sundanese Family
}

\author{
(Sistem Keyakinan Resiliensi Keluarga: Studi Fenomenologi pada Keluarga Suku Jawa dan \\ Suku Sunda)
}

\author{
Eem Munawaroh ${ }^{1 *}$, D. Y. P. Sugiharto ${ }^{1}$, Afriyadi Sofyan ${ }^{1}$, Firdian Setiya Arinata ${ }^{1}$, Zahra \\ Permata Budi Asti ${ }^{1}$, Esya Anesty Mashudi ${ }^{2}$ \\ ${ }^{1}$ Department of Guidance and Counseling, Faculty of Education, Universitas Negeri Semarang, \\ Sekaran St., Semarang, Central Java, 50229 Indonesia \\ ${ }^{2}$ Early Childhood Teacher Education Study Program, Faculty of Educational Science, Universitas Pendidikan Indonesia, \\ Setiabudhi St., No. 229, Bandung, West Java, 40154 Indonesia \\ *corresponding author, e-mail: eemmunawaroh@mail.unnes.ac.id
}

Article received: February $15^{\text {th }} 2021$; revised: March 31 $1^{\text {st }} 2021$; accepted: April $19^{\text {th }} 2021$

\begin{abstract}
The purpose of this study was to determine family resilience based on the belief system in families with Javanese and Sundanese cultural backgrounds. The method used in this study is a qualitative phenomenological method. Phenomenological studies are used to understand phenomena at the level of subjective reality. Respondents in this study were five families with Javanese ethnic background domiciled in Kebumen and Banyumas regencies, Central Java and three families with Sundanese cultural background domiciled in Pangandaran and Sumedang regencies, West Java. The data collection method using in-depth interviews based on the concept of family resilience from Walsh describes three aspects of the belief system. The research data was analyzed using the Miles and Huberman model, which consists of three stages: data reduction, data presentation, and drawing conclusions with the help of qualitative data analysis software, namely Nvivo 12 Plus. The results show that families with Javanese and Sundanese backgrounds have a belief system in facing life's trials which are manifested in the ability to interpret life's difficulties, have a positive outlook, and the value of religiosity. The results of this study can be used as part of an assessment in schools and information on family resilience can be used as a counselor's consideration in implementing family counseling and multicultural counseling services.
\end{abstract}

Keywords: family resilience; belief system; Javanese culture; Sundanese culture

\begin{abstract}
Abstrak: Tujuan penelitian ini adalah untuk mengetahui resiliensi keluarga berdasarkan sistem keyakinan pada keluarga dengan latar belakang budaya Jawa dan Sunda. Metode yang digunakan dalam penelitian ini adalah metode kualitatif fenomenologi. Studi fenomenologi digunakan untuk memahami fenomena pada tingkat realitas subjektif. Responden dalam penelitian ini adalah lima keluarga berlatar belakang etnis Jawa yang berdomisili di Kabupaten Kebumen dan Banyumas, Jawa Tengah dan tiga keluarga berlatar belakang budaya Sunda yang berdomisili di Kabupaten Pangandaran dan Sumedang, Jawa Barat. Metode pengumpulan data menggunakan wawancara mendalam berdasarkan konsep resiliensi keluarga dari Walsh yang menggambarkan tiga aspek sistem keyakinan. Data penelitian dianalisis menggunakan model Miles dan Huberman yang terdiri dari tiga tahapan yakni reduksi data, penyajian data, dan penarikan kesimpulan dengan bantuan software analisis data kualitatif yakni Nvivo 12 Plus. Hasil penelitian menunjukkan bahwa keluarga dengan latar belakang Suku Jawa dan Sunda memiliki sistem keyakinan dalam menghadapi cobaan hidup yang diwujudkan dalam kemampuan untuk memaknai kesulitan hidup, memiliki pandangan yang positif, dan nilai religiusitas. Hasil penelitian ini dapat dijadikan bagian dari asesmen di sekolah dan informasi resiliensi keluarga dapat dijadikan pertimbangan konselor dalam pelaksanaan layanan konseling keluarga dan konseling multikultural.
\end{abstract}

Kata kunci: resiliensi keluarga; sistem keyakinan; budaya Jawa; budaya Sunda 


\section{INTRODUCTION}

The development of life in society with various events that cannot be anticipated can put the family at a disadvantage. For example, the occurrence of the Covid-19 pandemic has caused families to be faced with the problem of declining income or unemployment (Kalil et al., 2020). These conditions require families to have resilience in facing difficult times in life. Family resilience is the ability of the family to actively generate strength when the family is faced with pressure and crisis (Oh \& Chang, 2014; Patterson, 1995).

Weak family resilience can put families in a position that is easy to experience various crisis such as disharmony in the household, discrimination, lack of communication between family members, lack of respect and belonging, exploitation and even murder in the family (Kolipah \& Devy, 2016). Other problems in the family such as conflict between family members, divorce, competition between siblings, and domestic violence, can have an impact on mental health problems such as depression and anxiety as well as maladaptive behavior such as aggressiveness in children and adolescents and even infidelity to husband and wife (Ediati et al., 2020). The presence of a family when children experience difficult times in their lives does have a significant positive impact on children's growth (Herdiana et al., 2018).

One of the important predictors of family resilience is culture. Culture can influence family structures, rituals, and practices that families carry out in a given culture (Black \& Lobo, 2008). In fact, understanding cultural differences can increase the development of appropriate interventions to support increasing family resilience (McCubbin et al., 1996; White et al., 2002). Therefore, the role of culture can be utilized to obtain a source of strength in increasing family resilience (Azizah \& Pudjiati, 2020).

In Indonesia, especially the island of Java, the majority of the population is Javanese and Sundanese. Based on the 2020 population census results, the majority of the population of Java Island is the Javanese with a total of 77.21 million and the Sundanese at 48.27 million out of a total of 270.20 million people (Statistics Indonesia, 2020). Regarding the COVID-19 pandemic, Java Island is the area most affected by the Covid-19 pandemic, especially in economic activity. In other words, families with Javanese and Sundanese backgrounds as the majority population who inhabit the island of Java are facing life challenges, one of which is caused by economic problems (Laucereno, 2020).

Characteristics related to resilience between Javanese and Sundanese have been widely studied. One of them reveals that parents with Javanese ethnic backgrounds can internalize positive characters such as sincerity, firmness, and religious values to the next generation to form the entrepreneurial spirit of children (Hermawan et al., 2018). The positive character is in accordance with aspects related to the development of family resilience (Rahmati et al., 2017). Furthermore, religious values, two-way communication, and behavioral control in Javanese families can prevent juvenile delinquency (Casmini \& Supardi, 2020).

Sundanese culture is known to be close to religious values (Ninin, 2015, Anshori, 2018), especially the religious values of Islam. The value of Islamic religiosity that contributes to the formation of Sundanese culture is reflected in daily worship practices. Meanwhile, resilience values are reflected in daily interactions that show harmony between generations (Susanti \& Koswara, 2019). The slogan of the Sundanese namely silas, which is stand for "silih asah silih asih silih asuh" has the meaning of cooperation in building a life together by loving each other, supporting each other in knowledge, and guiding each other. These values become the main capital for the formation of a resilient family (Saleh et al., 2013).

Family resilience can be formed from a belief system that can increase alternative problem solving, healing, and development. In addition, family belief systems can help family members take lessons from every crisis, generate hope, and present transcendence or spirituality. (Walsh, 2003). The family belief system influences how the family perceives a crisis, suffering, as well as the ability to identify options available to overcome the crisis. A strong belief system in the family can help the family succeed in facing life's difficulties faced by the family.

So far, investigations into family resilience have focused more on risk (Barnová \& Tamášov, 2018), a protective factor owned by the family (Blair, 2003), as well as certain vulnerability groups such as children with maltreatment (Meng et al., 2018). A more in-depth study of the family belief system, how the family interprets difficulties, a positive view of the family and family spirituality needs to be done. 
This is because the family belief system, the meaning of the family on difficulties, a positive view of the family and family spirituality are the basis for the formation of family resilience. A resilient family is the leading supporter of the development of positive characteristics in children.

Families that have positive interactions with other family members, especially children and apply religious values such as praying are proven to be able to apply parenting patterns with low-stress levels so that children have openness to parents and are more prepared to face daily problems (Mackay, 2003). Therefore, the purpose of this study was to identify belief systems in families with Sundanese and Javanese backgrounds. The results of this study can be used as part of a school assessment and can be used as consideration for school counselors in implementing family counseling and multicultural counseling services.

\section{METHOD}

The method used in this study was a qualitative phenomenological. Phenomenological studies are used to understand phenomena at the level of subjective reality (Strauss \& Corbin, 2013). This study tries to identify a family belief system with a Javanese and Sundanese background based on the concept of Walsh (2003). Subject recruitment was done by snowballing technique. The subjects consisted of five families with Javanese ethnic background domiciled in Kebumen and Banyumas regencies, Central Java, Indonesia and three families with Sundanese cultural backgrounds domiciled in Pangandaran and

Table 1. Family Belief System Resilience Interview Guidelines

\begin{tabular}{|c|c|c|}
\hline Indicator & Subindicator & Questions \\
\hline \multirow[t]{4}{*}{$\begin{array}{l}\text { Meaning of } \\
\text { difficulties }\end{array}$} & $\begin{array}{l}\text { Families view resilience as } \\
\text { relationship-based. }\end{array}$ & $\begin{array}{l}\text { How do you view the strength/strength of the } \\
\text { family? }\end{array}$ \\
\hline & $\begin{array}{l}\text { Normalization and contextualization } \\
\text { of difficulties (adversity). }\end{array}$ & $\begin{array}{l}\text { Do you think that trials and difficulties in the family } \\
\text { are common? Explain. }\end{array}$ \\
\hline & $\begin{array}{l}\text { The crisis presents a significant } \\
\text { challenge. }\end{array}$ & $\begin{array}{l}\text { How can the difficulties that you experience provide } \\
\text { life lessons? Explain. }\end{array}$ \\
\hline & $\begin{array}{l}\text { Explanation of the causes of } \\
\text { advertising. }\end{array}$ & $\begin{array}{l}\text { Do you understand the causes of the difficulties } \\
\text { faced by you? Explain. }\end{array}$ \\
\hline \multirow[t]{4}{*}{ Positive view } & $\begin{array}{l}\text { Hope, optimistic, confidence in } \\
\text { overcoming obstacles. }\end{array}$ & $\begin{array}{l}\text { When your family is faced with life's difficulties, } \\
\text { do you have hope that the difficulties will soon pass } \\
\text { and you are confident that you can overcome them? } \\
\text { Explain. }\end{array}$ \\
\hline & Courage and encouragement. & $\begin{array}{l}\text { How courageous are you in facing life's difficulties, } \\
\text { do you focus on the strength of your family? If yes/ } \\
\text { no please explain. }\end{array}$ \\
\hline & Perseverance. & $\begin{array}{l}\text { When you fail to overcome difficulties, do your } \\
\text { family give up or continue to try and believe that } \\
\text { they will find a way out? If yes/no please explain. }\end{array}$ \\
\hline & Purpose of life. & $\begin{array}{l}\text { Does your family have a purpose in life? If yes/no } \\
\text { please explain. }\end{array}$ \\
\hline \multirow[t]{3}{*}{$\begin{array}{l}\text { Transcendence } \\
\text { and spirituality }\end{array}$} & $\begin{array}{l}\text { Faith, religious friend support, } \\
\text { worship. }\end{array}$ & $\begin{array}{l}\text { How is belief in God and worship like praying in the } \\
\text { face of difficulties? If yes/no explain. }\end{array}$ \\
\hline & $\begin{array}{l}\text { Inspiration; identify new } \\
\text { possibilities, creative expression, } \\
\text { social action. }\end{array}$ & $\begin{array}{l}\text { Have the lessons that you have learned from } \\
\text { adversity have inspired you for a more meaningful } \\
\text { life (example: helping others). }\end{array}$ \\
\hline & $\begin{array}{l}\text { Transformation: learn, change, and } \\
\text { grow from advertising. }\end{array}$ & Have you become a better person? Explain. \\
\hline
\end{tabular}


Sumedang regencies, West Java, Indonesia. The difference in the number of samples between Javanese and Sundanese refers to the saturation of information obtained from each respondent (Guest et al., 2006). This means that the information obtained is quite representative and no new information is obtained. Thus, that the proportion of five Javanese families and three Sundanese families is considered sufficient.

Respondents were selected based on the following criteria: (1) having a Javanese or Sundanese cultural background, (2) living in a Javanese or Sundanese cultural environment, (3) implementing cultural activities (such as the use of language appropriate to their culture). As a fulfillment of the resilience assessment criteria, the selected respondents are respondents who have adversity criteria such as poverty, not working, or polygamy. Data collection was carried out by means of in-depth interviews with respondents. Prior to the interview, the respondent signed a consent form to become a respondent (informed consent). Data were analyzed using Miles and Huberman model data analysis, consisting of three stages, namely data reduction, data presentation, and conclusion drawing (Rijali, 2019) with the help of qualitative data analysis software, Nvivo 12 Plus. There are 12 questions asked to respondents to reveal the family belief system (Walsh, 2003). In-depth interviews revealed three family belief systems indicators: understanding of difficulties, positive views, and transcendence or spirituality. In more detail, the interview guidelines containing indicators are presented in table 1.

\section{RESULTS}

The family belief system seeks to reveal three important aspects: the family's meaning of difficulties, a positive view of the family, and transcendence or family spirituality. The following are the results of the research on each aspect based on the Javanese and Sundanese.

\section{The Javanese Family's Meaning of Difficulties}

Families with Javanese backgrounds interpret that family strength comes from trust, confidence and cooperation between family members. Like the following expression:

"What is clear is honesty, complementing each other, taking care of each other. The point is cooperation.

The basis of cooperation. Yes, the main thing is honesty" (RSJ 3)

Javanese families view that difficulties are normal in everyday life. Understanding is the key in dealing with these difficulties. Difficulty gives rise to various meanings, such as being able to set priorities in life, especially related to the economy, namely which needs must come first, having patience, better financial management, hard work and as a provision of experience to face difficulties in the future. Like the following expression:

"The current lesson is clear, first you have to be more active, try hard, keep trying to save money, then you have to study again" (RSJ 4)

Families with a Javanese background view that the difficulties they face stem from a weak economy, overthinking and low education. Like the following expression:

"Education, yes. Education. First, maybe because of my inability to absorb education in the past. So, in

the future, don't be like me, kids. It must be even higher" (RSJ3)

In more detail and comprehensively, the meaning of Javanese families towards difficulties is presented in Figure 1.

\section{The Sundanese Family's Meaning of Difficulties}

Families with Sundanese backgrounds understand family resilience as a relationship based on patience, economic strength, mutual forgiveness between family members, trust, and responsibility. Like the following expression:

"From the understanding of the family, the basis of mutual trust and responsibility, a good and affluent economy" (RSS1)

The Sundanese family view that life's difficulties are commonplace and give various meanings, namely submission to God, sincerity, prayer, and gratitude. The Sundanese family views that the cause of the difficulties they face is the economy as expressed by the following respondents: 


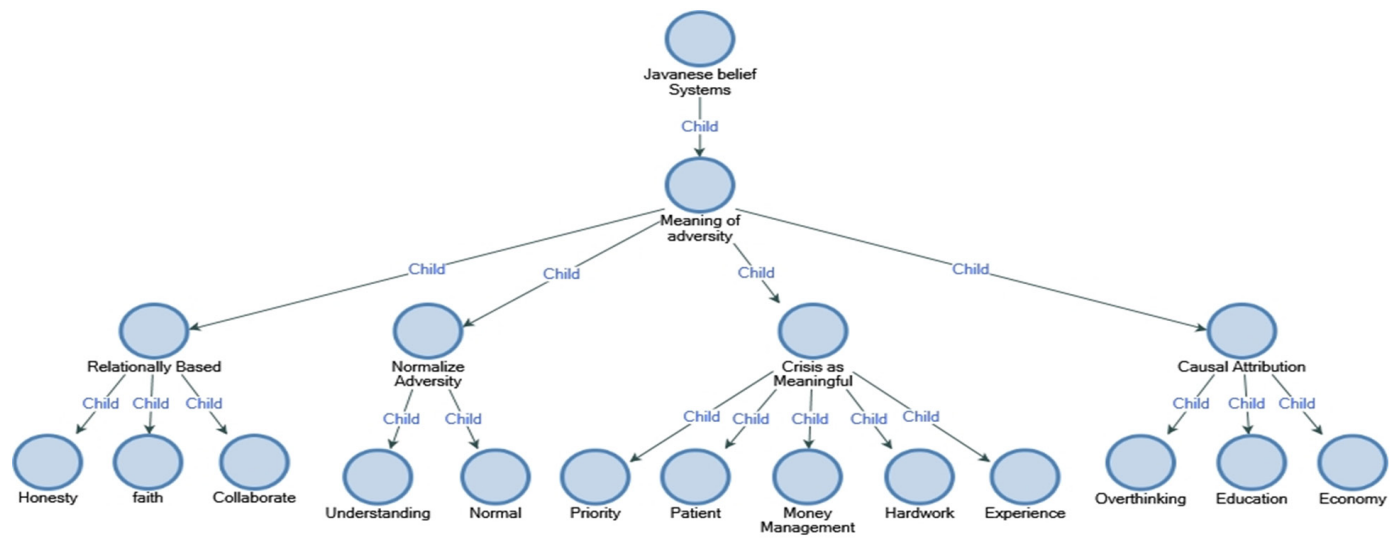

Figure 1. The Javanese Meaning of Life's Difficulties

"Sometimes, from trade, there is a loss, it doesn't sell, a lot of people owe but don't pay it, but it's okay to just replace it with God. (RSS3)

In more detail and comprehensively, the meaning of the Sundanese family to difficulties is presented in Figure 2.

\section{The Positive View of the Javanese Family on Life's Difficulties}

Families with Javanese ethnic backgrounds have optimism in facing life's difficulties, namely having self-confidence and being based on religion. This optimism is accompanied by encouragement and enthusiasm in the family to encourage each other accompanied by honesty and trust in the family, as the following expression:

"The most important thing is honesty, for example, if we have money or not. We should only buy something that we really need" (RSJ3)

The positive view of the family is manifested by perseverance to find a way out, namely by continuously trying to get out of the difficulties of life. Like the following expression:

"I keep trying, no matter how difficult it is. I keep trying until I can succeed. I am not giving up. At that time, I joined Multi-Level Marketing (MLM). Yes, I've gone everywhere, but the result is 0. I'm being tricked by my boss. In the end, I jumped into another business. I am delivering groceries to various cities. So. Alhamdulillah, it can cover the shortfall" (RSJ5)

Optimism, enthusiasm, and optimism in families with Javanese backgrounds are accompanied by acceptance of the things that cannot be changed in life. Namely the understanding that what happened was the destiny of the Almighty God.

"If it is destiny, we must be sincere. We have to accept and surrender. Maybe you can't get it at first.

But we have to learn and try to accept the thing that happens to us" (RSJ1)

In more detail and comprehensively, the positive view of Javanese families towards the difficulties of life is presented in Figure 3.

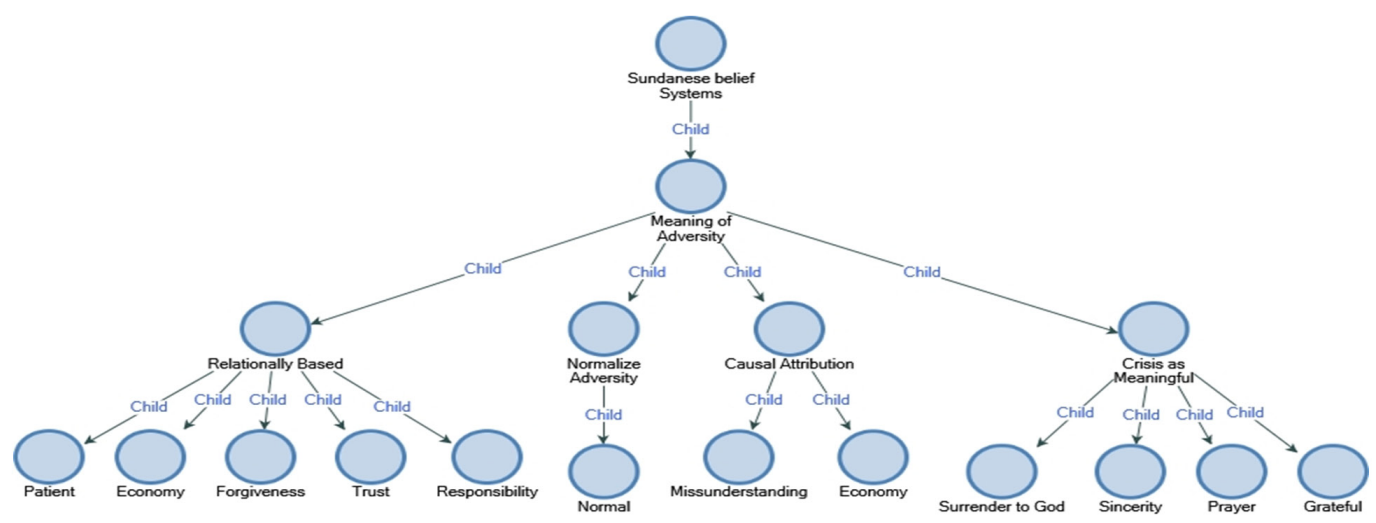

Figure 2. The Meaning of the Sundanese Family to the Difficulties of Life 


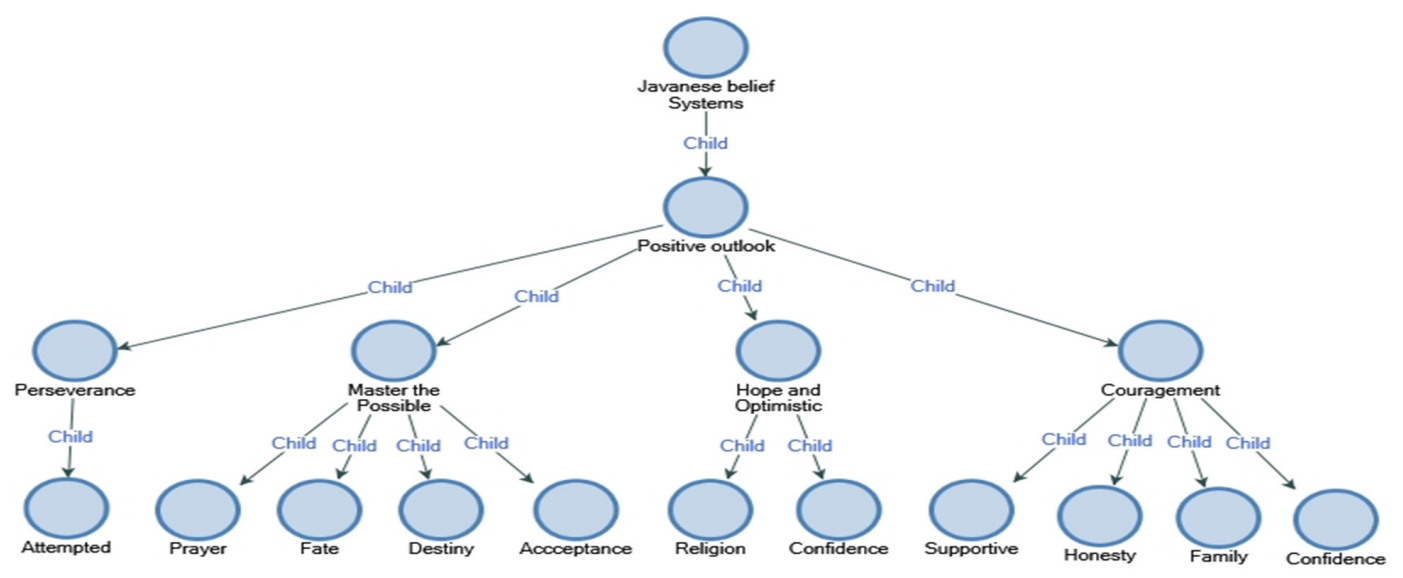

Figure 3. The Positive View of the Javanese Family on Life's Difficulties

\section{Positive Views of the Sundanese Family on Life's Difficulties}

The positive view of a family with a Sundanese background towards life's difficulties is manifested by optimism that they will get out of trouble accompanied by belief and prayer to God. Optimism and enthusiasm with prayer and belief are accompanied by establishing a good relationship with both parents as a form of worship. Families with Sundanese backgrounds have perseverance in worship, submission to the Almighty God, and acceptance.

"Yes, surrender because life is all predetermined" (RSS3).

In addition to having hope, optimism, and encouragement to face difficulties, families with Sundanese backgrounds are able to accept the things that cannot be changed in life accompanied by surrender to the Almighty God. In more detail and comprehensively, the positive view of the Sundanese tribal family towards the difficulties of life is presented in Figure 4.

\section{Javanese Family Spirituality Facing Life's Difficulties}

Families with Javanese ethnic backgrounds have various life goals, namely happiness in life, family success, especially children, and long-term goals, namely going to heaven. This is supported by worship rituals such as praying (for Muslims).

"I want to make my children successful, live comfortably and happily, not hungry, not far behind with my family, meaning the economy" (RSJ3)

The difficulties of life inspire families with Javanese cultural backgrounds to have patience, share and help others in the midst of difficulties. This inspiration supports the transformation to become a stronger, sincere, and patient family. In more detail and comprehensively, the spirituality of Javanese families when facing life's difficulties is presented in Figure 5.

\section{Sundanese Family Spirituality Against Life's Difficulties}

Families with Sundanese backgrounds have various life goals, namely family success, especially children, happiness, success, knowledge, and serenity in carrying out worship. This is supported by worship rituals such as praying.

"Live successful in the world, go to heaven, children have a good education, are knowledgeable" (RSS 2)

The inspiration obtained by families with Sundanese cultural backgrounds is that they can help others in the midst of difficulties and can transform into families who are diligent in worshiping, devoted to their mothers, and have patience. In more detail and comprehensively, the spirituality of the Sundanese family when facing life's difficulties is presented in Figure 6. 


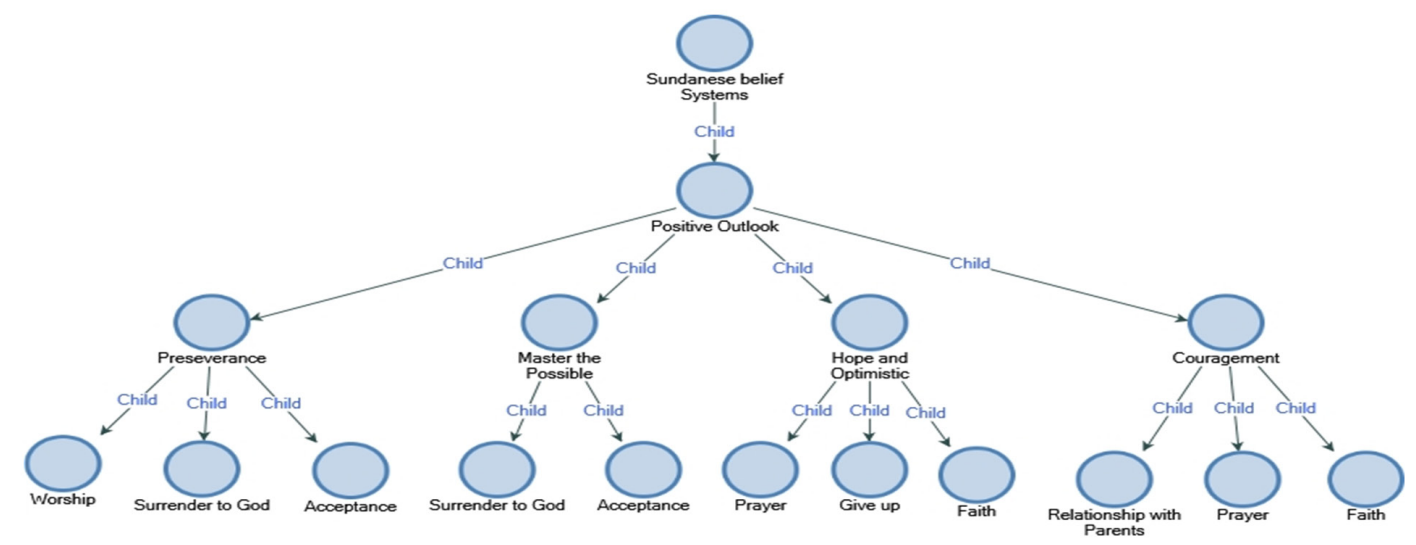

Figure 4. Positive Views of the Sundanese Family on Life's Difficulties

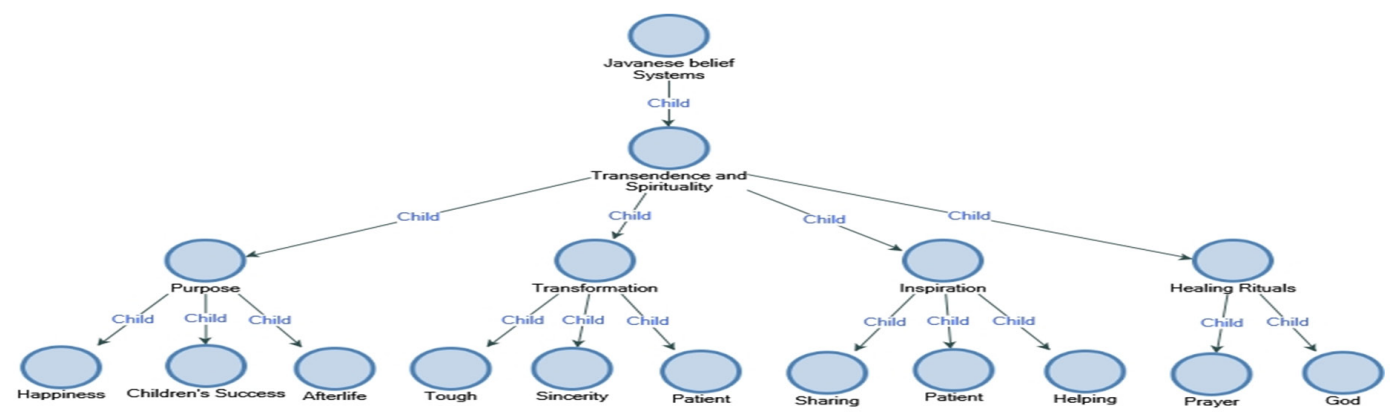

Figure 5. Javanese Family Spirituality Facing Life's Difficulties

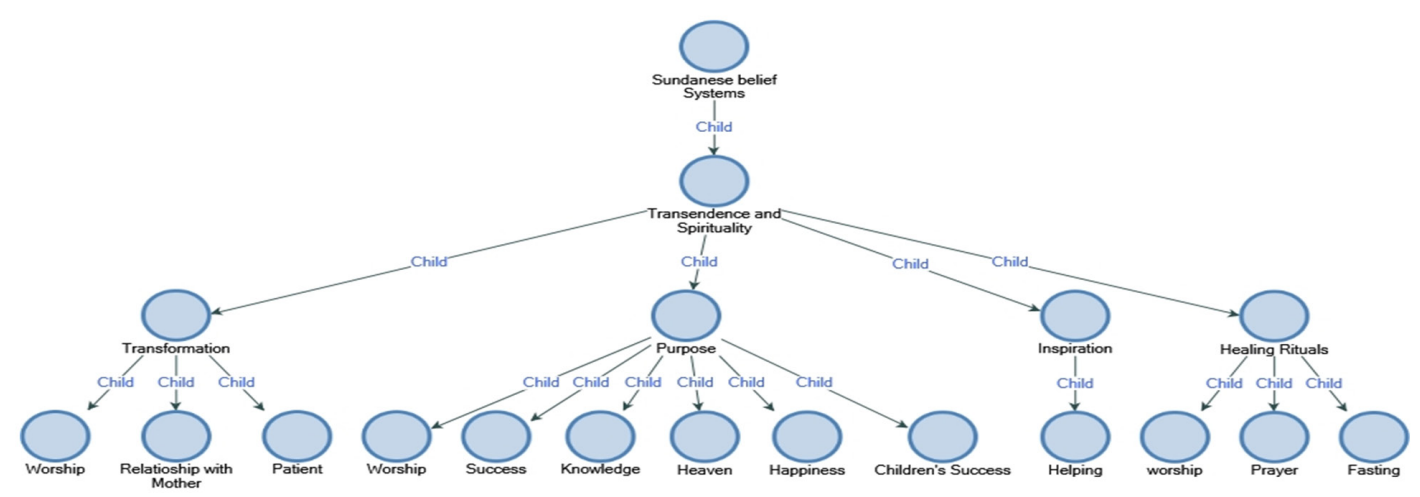

Figure 6. Sundanese Family Spirituality Faces Life's Difficulties

\section{DISCUSSION}

A belief system is a structure or norm of an individual or group of people that influence how they perceive the reality of life. Belief systems define what is good and bad in an individual or community, perspective, and life orientation (Usó-Doménech \& Nescolarde-Selva, 2016). Walsh (2003) using belief systems, organizational patterns, and communication and problem-solving skills in the family as criteria for revealing family resilience. In family resilience, the family belief system describes the family's view of the reality of the difficulties they face based on the meaning of the difficulties themselves, positive views of difficulties, and spirituality that influences the family in viewing difficulties.

In interpreting the difficulties of life, families with Javanese backgrounds understand that family strengths, namely honesty, belief, and collaboration, are the most important for families in facing life's difficulties. This understanding is accompanied by the family's view that difficulties are normal. The difficulties caused by the low economy and education mean that the family must continue to be patient, work hard, have life priorities and better financial management. The typical beliefs that exist are factors 
that support family resilience as described by Walsh (2003) that one of the indicators of family resilience based on a belief system is the normalization and contextualization of life difficulties which act as milestones that must be faced to make the family stronger in facing the challenges of life in the future.

One of the meanings of the Javanese family from the trials of life is the importance of setting priorities and having effective financial management. This is in accordance with Javanese cultural values, namely "gemi" which means good at saving. Gemi is a characteristic that spending money carefully, does not mean being stingy but can distinguish what to buy first. Gemi can also be interpreted as regulating the balance between income and spending money (Budiyono \& Feriandi, 2017). The Javanese cultural value of "gemi" can contribute to family resilience when facing life's challenges and difficulties.

The Sundanese family has an understanding of the strength of the family as the basic capital of the family in facing life's difficulties. Patience, responsibility, economic strength, mutual trust, and forgiveness are the capital of the Sundanese family in facing life's difficulties. Families with a Sundanese background understand difficulties as normal due to a lack of effective communication and economic hardship. Sundanese families interpret difficulties as opportunities to always be grateful, sincere, pray, and surrender to the Almighty God.

Sundanese families relate the difficulties of life they face with signs that the family must get closer to God through the implementation of daily worship such as prayer, fasting, and dhikr. Religiosity and spirituality are the peculiarities of the Sundanese family in the formation of resilience. This is in line with research by Reis and Menezes (2017) on 14 adults in Brazil who use religious activities such as reading the Bible and praying as a coping mechanism to face life's difficulties, maintain family health, and as a form of family protection.

On the positive aspect, families with Javanese and Sundanese backgrounds both have a positive outlook in the midst of a less favorable situation. A positive outlook is indicated by hope and optimism, support, persistence, and acceptance of the unchangeable. Resilience is closely related to positivism. Even resilience itself is part of positive psychology. A study shows that hope, optimism and resilience are closely related to maintaining positive behavior in organizations (Malik, 2013).

The positive view of the Sundanese is very closely related to religious values. A positive view of the life difficulties of the Sundanese family is manifested through worship activities, submission to God, and prayer. Sundanese culture is often associated with high religiosity. Religious values, especially Islam, are evident in cultural rituals such as circumcision, death, inheritance, muamalah or the economy (Sujati, 2020). The values of religiosity in Sundanese culture are protective factors for the formation of family resilience as well as the close relationship between religiosity and resilience (Nihayati et al., 2020; Nelson-Becker \& Thomas, 2020; Javanmard, 2013).

Spiritual values become part of family resilience based on the strength, comfort, and guidance from spiritual beliefs and worship practices. The Javanese and Sundanese have short and long-term life goals, rituals of worship, thereby inspiring and encouraging family transformation. In a family with Javanese family background, happiness, success, and heaven are the goals of life. While in the Sundanese family, besides these three things, knowledge, serenity and solemnity of worship are also included as the main goal in life.

Religious spiritual practices carried out by both the Sundanese and the Javanese are prayer, and fasting. The difficulties in life faced by families with Javanese cultural backgrounds inspire them to share, help others, and have patience in the next life and transform into a stronger, sincere, and patient family in the face of trials in the future. In the Sundanese, the inspiration obtained is to help others and transform into a person who is more patient, diligent in worship, and devoted to parents, especially mothers.

Patience is a character that often appears in interviews with families with Javanese backgrounds. Patience is closely related to Javanese culture. Patience is the ability to control emotions and desires, as well as the ability to endure unpleasant situations without complaining. In Javanese culture, several terms are held that reflect patience, such as "wong sabar pasti subur" which means people who are patient will be successful, "wong sabar rejekine jembar, wong ngalah, uripe berkah" which means people who are patient will be lucky and have a happy, blessed life. Patience is one of the characteristics of a family with a Javanese background that can be a protective factor for family resilience as there is 
a close relationship between patience and resilience (Bostan, 2015). Maintaining good relations with parents, especially with mothers, is very important for families with a Sundanese background. Blessings obtained from filial piety to parents, especially mothers, can give happiness in life.

The results of this study have significant implications for guidance and counseling services in schools. The school counselor's understanding of the resilience of Javanese and Sundanese families, especially the family belief system, can be a reference in providing guidance and counseling services, especially family counseling and multicultural counseling. Counselors can help counselees make effective decisions in dealing with problems faced by families based on the counselor's understanding of the counselee's views on the problems faced, expectations, and protective factors such as religiosity.

\section{CONCLUSION}

Families with Javanese and Sundanese backgrounds have a belief system in facing life's trials. The belief system is manifested in the ability to interpret the difficulties of life, have a positive outlook, and the value of religiosity. One of the capitals of family resilience in the Javanese is the ability to manage finances and patience, while in the Sundanese it is the practice of worship and the attachment of relationships with the closest people, especially mothers. Subsequent research can identify more deeply about the implementation of financial management skills and patience in families with Javanese family backgrounds and worship practices. In addition, further research can also explore the attachment of the Sundanese to their parents, especially to their mother, as one of the aspects that influence the formation of family resilience.

\section{REFERENCES}

Anshori, D. S. (2018). The construction of Sundanese culture in the news discourse published by local mass media of West Java. Lingua Cultura, 12(1), 31-38. https://doi.org/10.21512/lc.v12i1.3370

Azizah, L. N., \& Pudjiati, S. R. R. (2020). Kontribusi identitas budaya jawa yang dimediasi oleh cognitive reappraisal dalam membentuk resiliensi keluarga pada keluarga Suku Jawa. Analitika, 12(1), 10-21. https:// doi.org/10.31289/analitika.v12i1.2815

Barnová, S., \& Tamášov, V. (2018). Risk and protective factors in the life of youth in relation to resilience. Psychológia a patopsychológia, 52(1), 50-59. https://doi.org/10.2478/papd-2018-0001

Black, K., \& Lobo, M. (2008). A conceptual review of family resilience factors. Journal of Family Nursing, 14(1), 33-55. https://doi.org/10.1177/1074840707312237

Blair, R. G. (2003). Understanding and fostering family resilience. Journal of Family Strengths, 7(1), 43-56.

Bostan, C. M. (2015). The role of motivational persistence and resilience over the well-being changes registered in time. Symposion, 2(2), 215-241. https://doi.org/10.5840/symposion20152212

Budiyono, \& Feriandi, Y. A. (2017). Menggali nilai nilai kearifan lokal budaya jawa sebagai sumber pendidikan karakter. Prosiding SNBK (Seminar Nasional Bimbingan dan Konseling), 1(1), 92-103. http://prosiding. unipma.ac.id

Casmini, C., \& Supardi, S. (2020). Family resilience: Preventive solution of Javanese youth klithih behavior. The Qualitative Report, 25(4), 947-961. https://doi.org/10.46743/2160-3715/2020.4361

Ediati, A., Salma, S., \& Kaloeti, D. V. S. (2020). Perceptions of family hurdles among emerging adults: A preliminary study about resilience in the Indonesian family. Jurnal Psikologi, 19(1), 15-25.

Guest, G., Bunce, A., \& Johnson, L. (2006). How many interviews are enough?: An experiment with data saturation and variability. Field Methods, 18(1), 59-82. https://doi.org/10.1177/1525822X05279903

Herdiana, I., Suryanto, D., \& Handoyo, S. (2018). Family resilience: A conceptual review. Proceedings of the $3 r d$ ASEAN Conference on Psychology, Counselling, and Humanities (ACPCH 2017). https://doi.org/10.2991/ acpch-17.2018.9

Hermawan, A., Arief, M., \& Rahayu, W. P. (2018). Dimensions of the Javanese culture and the role of parents in instilling values in creative industry entrepreneurship. International Journal of Engineering \& Technology, $7(2), 182-189$.

Javanmard, G. H. (2013). Religious beliefs and resilience in academic students. Procedia - Social and Behavioral Sciences, 84, 744-748. https://doi.org/10.1016/j.sbspro.2013.06.638 
Kalil, A., Mayer, S., \& Shah, R. (2020). Impact of the COVID-19 crisis on family dynamics in economically vulnerable households. SSRN Electronic Journal, 1. https://doi.org/10.2139/ssrn.3706339

Kolipah, S., \& Devy, S. R. (2016). Pengaruh ketahanan keluarga terhadap kegemaran bermain game online pada siswa SD di Kelurahan Mulyorejo. Jurnal Promkes: The Indonesian Journal of Health Promotion and Health Education, 4(1), 104-115.

Laucereno, S. F. (2020). Kepala Bappenas sebut ekonomi RI bisa minus 1,1\% tahun ini. Detikfinance. https:// finance.detik.com/berita-ekonomi-bisnis/d-5227358/kepala-bappenas-sebut-ekonomi-ri-bisa-minus-11tahun-ini

Mackay, R. (2003). Family resilience and good child outcomes: An overview of the research literature. Social Policy Journal of New Zealand, 20, 98-118.

Malik, A. (2013). Efficacy, hope, optimism and resilience at workplace - Positive organizational behavior. International Journal of Scientific and Research Publications, 3(10), 1-4.

McCubbin, H. I., Thompson, A. I., \& McCubbin, M. A. (1996). Family assessment: Resiliency, coping and adaptation: Inventories for research and practice. University of Wisconsin-Madison, Center for Excellence in Family Studies.

Meng, X., Fleury, M. J., Xiang, Y. T., Li, M., \& D'arcy, C. (2018). Resilience and protective factors among people with a history of child maltreatment: A systematic review. Social Psychiatry and Psychiatric Epidemiology, 53(5), 453-475. https://doi.org/10.1007/s00127-018-1485-2

Nelson-Becker, H., \& Thomas, M. (2020). Religious/spiritual struggles and spiritual resilience in marginalised older adults. Religions, 11(9), 1-17. https://doi.org/10.3390/rel11090431

Nihayati, H. E., Maulida, R. F., \& Wahyuni, E. D. (2020). The relationship of religiosity with resilience of adultassisted residents in community institutions. Systematic Reviews in Pharmacy, 11(6), 1111-1115. https://doi. org/10.31838/srp.2020.6.159

Oh, S., \& Chang, S. J. (2014). Concept analysis: Family resilience. Open Journal of Nursing, 4(13), 980-990. https://doi.org/10.4236/ojn.2014.413105

Patterson, J. M. (1995). Promoting resilience in families experiencing stress. Pediatric Clinics of North America, $42(1), 47-63$.

Rahmati, M., Khaledi, B., Salari, N., Bazrafshan, M. R., \& Haydarian, A. (2017). The effects of religious and spiritual interventions on the resilience of family members of patients in the ICU. Shiraz E-Medical Journal, 18(11), e13007. https://doi.org/10.5812/semj.13007

Reis, L. A. D., \& Menezes, T. M. D. O. (2017). Religiosity and spirituality as resilience strategies among longliving older adults in their daily lives. Revista Brasileira de Enfermagem, 70(4), 761-766. https://doi. org/10.1590/0034-7167-2016-0630

Rijali, A. (2019). Analisis data kualitatif. Alhadharah: Jurnal Ilmu Dakwah, 17(33), 81-95.

Saleh, F., Soejadi, \& Lasiyo. (2013). Makna "Silas" menurut kearifan budaya Sunda perspektif filsafat nilai: Relevansinya bagi pemberdayaan masyarakat miskin. Sosiohumaniora, 15(2), 158-166. https://doi. org/10.24198/sosiohumaniora.v15i2.5745

Statistics Indonesia. (2020). Hasil Sensus Penduduk. https://www.bps.go.id/pressrelease/2021/01/21/1854/hasilsensus-penduduk-2020.html

Strauss, A., \& Corbin, J. (2013). Dasar-dasar penelitian kualitatif. Yogyakarta: Pustaka Pelajar.

Sujati, B. (2020). Tradisi budaya masyarakat Islam di tatar Sunda (Jawa Barat). Ishlah: Jurnal Ilmu Ushuluddin, Adab dan Dakwah, 1(1), 37-51. https://doi.org/10.32939/ishlah.v1i1.29

Susanti, S., \& Koswara, I. (2019). Concept of silih asih, silih asah, silih asuh in the aculturation in Bandung. Proceedings of the 3rd Annual International Seminar and Conference on Global Issues (ISCoGI 2017), 1317. Atlantis Press. https://doi.org/10.2991/iscogi-17.2019.4

Usó-Doménech, J. L., \& Nescolarde-Selva, J. (2016). What are belief systems? Foundations of Science, 21(1), 147-152. https://doi.org/10.1007/s10699-015-9409-z

Walsh, F. (2003). Family resilience: A framework for clinical practice. Family Process, 42(1), 1-18. https://doi. org/10.1111/j.1545-5300.2003.00001.x

White, N., Richter, J., Koeckeritz, J., Lee, Y., \& Munch, K. L. (2002). A cross-cultural comparison of family resiliency in hemodialysis patients. Journal of Transcultural Nursing, 13(3), 218-227. https://doi. org/10.1177/10459602013003011 